\title{
The acaricidal effect of peracetic acid against Boophilus annulatus and Argas persicus
}

\author{
Efeito acaricida do ácido peracético \\ contra Boophilus annulatus e Argas persicus
}

Hanem Fathy Khater \& Mohamed Youssef Ramadan

\begin{abstract}
The acaricidal activity of peracetic acid, PAA, against the cattle tick, Boophilus annulatus, and the fowl tick, Argas persicus was tested using filter paper contact bioassay. PAA had a great potential as acaricide and its effectiveness increased with increasing concentration and exposure time. Two minutes after treatment with $0.5 \%$, PAA induced $100 \%$ mortality of both tick species and LC50 values for cattle and fowl ticks, after treatment for $30 \mathrm{~min}$, were 0.06 and $0.05 \%$, respectively. Following treatment with $0.25 \%$, the LT50 values were 0.02 and $3.12 \mathrm{~min}$, respectively. Furthermore, the detrimental effect of PAA against cattle tick extended beyond the adult stage, it significantly prolonged the preoviposition period, shortened the oviposition period, and decreased the mean number of the layed eggs, such parameters were 14.75 and 6.57 days, as well as 457.50 , respectively, after treatment with $0.25 \%$ of PAA. Therefore, PAA is highly effective when used at lower doses and short exposure time. The high speed of killing ticks is very important for avoidance of the hazard ensued by pathogen transmission in the course of delayed mortality caused by the currently used acaricides.
\end{abstract}

Key words: Boophilus annulatus, Argas persicus, acaricide, peracetic acid.

\section{RESUMO}

A atividade acaricida do ácido peracético, PAA, contra os carrapatos bovinos Boophilus annulatus, de aves, Argas persicus foi testada pelo uso do sistema de filtro de papel. O PAA mostrou um grande potencial acaricida e os efeitos aumentaram com o aumento da concentração e tempo de exposição ao produto. Dois minutos após o tratamento com 0,5\%, o PAA causou $100 \%$ de mortalidade em ambas as espécies. O valor de LC50 foram, respectivamente, 0,06 e 0,05\%, para o tratamento de 30 minutos. O tratamento com 0,25\%, teve um LT50 de, respectivamente, 0,02 e 3,12 min. Além disso, os danos causados pelo tratamento com $0,25 \%$ de PPA atingiram a fase adulta do carrapato, prolongando o tempo de pré-postura (14,75 dias), reduzindo o período de postura (6,57 dias) e número de ovos (457,50). Portanto, o PPA é altamente eficaz, mesmo quando usado em baixas doses e por curso períodos de exposição. A grande velocidade para matar os carrapatos é muito importante para evitar o perigo de transmissão de.

Descritores: Boophilus annulatus, Argas persicus, acaricida, ácido peracético. 


\section{INTRODUCTION}

Ticks are very important ectoparasite of domestic animals [48,57]. The cattle tick, Boophilus annulatus (Say 1821) not only affected production of cattle when found in large numbers [57], but also the vector of many viral and rickettsial diseases in Africa [48] and babesiosis, the most important disease [16,57,48].

The fowl tick, Argas persicus (Oken) is of considerable veterinary importance as a parasite of poultry and wild birds causing weakness, anemia [7,57] reduction in egg production and growth, in addition to death of poultry $[8,47]$. Such tick is the vector of fowl spirochaetosis [52,57]. Moreover, three species of bacteria, Staphylococcus aureus, Salmonella pullorum, and Escherichia coli were isolated recently from this species [52].

The emphasis on pest control operations to reduce transmission of vector-borne diseases in the past included area wide application of synthetic pesticides potentially leading to environmental contamination such as soil and ground water pollution, adverse effect on non target species, and resistance in arthropod pests [12,33,51]. B. microplus (Canestrini) has developed resistance to many classes of acaricides $[5,17,33,34$, $40,50]$. Such resistance in tick presents a growing threat to the agricultural animal industry world wide [58].

PAA has strong germicidal activity, thus the center of disease control of the united states have listed this compound as high level disinfectant [10] and used as sterilizing agent $[6,20,28,30,59]$. PAA is environment-friendly as the compound is decomposed to citric acid and water [60].

The objective of the work is to use PAA as novel and environmentally safe acaricide of high speed in killing ticks.

\section{MATERIAL AND METHODS}

Fully engorged $B$. annulatus females were collected from the ground of cattle pens at the farm of Faculty of Agriculture, Moshtohor, Benha University. Whereas, A. persicus larvae were collected from small flocks of chicken maintained for personal use in the rural area arround Benha city, Egypt.

Peracetic acid, PAA (Peroxyacetic acid), is commercially available and obtained from Al-Motaheda Co. Egypt.

\section{Bioassays for $B$. annulatus}

Regarding the concentration-response bioassay, studying the acaricidal property of PAA was done according to Pamo et al. [44]. Five doses of PAA with four replications for each concentration were used in vitro. Ten ticks per replicate were placed in a clean dry Petri dish with a filter paper, Disc of Whatman No.1 filter paper measuring $62.63 \mathrm{~cm}^{2}$ surface areas, impregnated uniformly with the used concentration of PAA on the bottom. The bioassay trails were carried out with increasing concentrations $(0.03,0.06,0.13,0.25$, and $0.5 \%)$ and contact time $(2,5,20$, and 30 minutes). The control groups were treated with distilled water. Bioassays were done at $27 \pm 2^{\circ} \mathrm{C}$ and $75 \pm 5 \% \mathrm{RH}$.

Ticks were considered alive if they exhibited normal behavior when breathed upon or physically stimulated with a wooden dowels. In addition to readings were taken after the previously mentioned contact time. For each time point, if ticks were incapable of movement, maintaining normal posture, leg coordination, ability to right themselves, or any signs of life, they were considered moribund or dead [46].

The time-response bioassay was similar to the standard concentration-response bioassay with the following exception; ticks were exposed to a single concentration for each trial. Moreover, the mortality was initially assessed $2 \mathrm{~min}$. after being subjected to PAA, followed by mortality assessment at 5, 20, 30, 60, and $120 \mathrm{~min}$. The used concentrations were $0.03,0.06,0.13$, and $0.25 \%$.

The survived treated engorged females, subjected to PAA for $30 \mathrm{~min}$., were incubated under $27^{\circ} \mathrm{C}$ and $75 \% \mathrm{RH}$. They were checked daily till the end of the oviposition periods. Some biological parameters were determined, such as the preoviposition, oviposition periods, and number of laid eggs.

\section{Bioassays for A. persicus}

Concerning the concentration mortality bioassay, the same procedure was done as previously mentioned for $B$. annulatus, with the following exceptions; the used concentrations were $(0.01,0.03,0.06$, $0.13,0.25$, and $0.5 \%)$ and contact time $(2,5,20,30$, and 60 minutes).

For the time-response bioassay, we follow the same technique that used for B. annulatus, except for some points; the applied concentrations $(0.01,0.03$, $0.06,0.13,0.25$, and $0.5 \%)$ and contact time $(2,5,20$, 30 , and 60 minutes).

With reference to data analysis, life and dead ticks were counted to determine the percentage of mortality. After that, such data were subjected to Pobit analysis by computer, POLO-PCO [22]. Consequently, 
the following parameters were estimated; the lethal concentration \%, LC50, and LC90 as will as the slop of the regression lines. Moreover, the lethal time LT estimates were calculated, LT50 and LT90. Duncan's multiple range test analyzed the biological data, by using the SPSS program.

\section{RESULTS}

\section{Bioassays for $B$. annulatus}

The concetration-response bioassay revealed the acaricidal efficacy of PAA on engorged $B$. annulatus female, Table 1. The acaricidal efficacy increased as the concentration of PAA and the exposure time increased. Two min. posttreatment, the mortality percentages were $90 \%$ and $100 \%$ following treatment of $0.25 \%$ and $0.5 \%$ PAA, respectively.

The results in Table 2 show the sensitivity of B. annulatus to PAA. After exposure for $2 \mathrm{~min}$., LC50 and LC90 values were $0.17 \%$ and $0.25 \%$, respectively.

With regard to the time response bioassay, Table 3 shows the LT values of PAA against hard tick. The LT50 and LT90 values were 0.02 and $3.02 \mathrm{~min}$., respectively, after treatment with $0.25 \%$.

Concerning the acaricidal effect of different concentrations of PAA on the biology of the survived female ticks, Table 4, it was noticed that higher concentrations prolonged the preoviposition periods of females, significantly different from that of the control. The longest pre-oviposition period, $14.75 \pm 0.48$ days, was recorded in female ticks that exposed to $0.25 \%$. Despite the prolonged effect of PAA on the pre-oviposition periods, the same concentration significantly shortened the oviposition periods, $6.75 \pm 0.48$ days, and decreased the number of laid eggs, 400-500 eggs.

\section{Bioassays for $A$. persicus}

Tables 5 and 6 represent the potential of PAA against soft tick $A$. persicus. The concentration mortality bioassay indicated that the larval mortality rates were concentration and time dependent relationship. PAA was highly efficient against soft tick larvae. As a result, $100 \%$ mortality was reached following treatment with lower concentrations $(0.5 \%$ after $2 \mathrm{~min}$. $0.25 \%$ after $5 \mathrm{~min}$, and $0.13 \%$ after $60 \mathrm{~min}$ ). After treatment for 2 minutes, LC50 and LC90 values were 0.35 and 0.37 , respectively.

About the time-response bioassay, PAA induced very expeditious acaricidal outcome against larvae of fowl tick, Table 7, since the LT50 and LT90 values were of lower values, 3.12 and $3.35 \mathrm{~min}$, respectively, following treatment with $0.25 \%$ PAA.

\section{DISCUSSION}

PAA provided evidence of acaricidal effect to both $B$. annulatus engorged females and A. persicus larvae. The efficacy increased as the concentration and exposure time increased.

With regard to mortality of $B$. annulatus following exposure to PAA, the highest concentration $0.5 \%$ killed all ticks after 2 min. LC50 values were $0.17-0.06 \%, 2-30$ min. post application. Till now and to our knowledge, no work has ever been conducted to evaluate the efficacy of PAA against ticks.

Ongoing in the past until this time, synthetic chemical acaricides are widely used in order to control ticks of medical and veterinary importance. Eradication of the cattle tick, B. annulatus, from the U.S. was accomplished long ago by dipping of cattle in arsenic and removing of cattle form infested pastures

\begin{tabular}{ccccccccc}
\multicolumn{7}{l}{ Table 1. Mortality percentage of Boophilus annulatus after treatment with PAA. } \\
\hline Time/min & \multicolumn{2}{c}{$\mathbf{2}$} & \multicolumn{2}{c}{5} & \multicolumn{2}{c}{20} & \multicolumn{3}{c}{30} \\
\hline Conc. \% & Alive & Dead & Alive & Dead & Alive & Dead & Alive & Dead \\
0.03 & 100 & 0.00 & 100 & 0.00 & 100.00 & 0.00 & 83.33 & 16.67 \\
0.06 & 100 & 0.00 & 93.33 & 6.67 & 60.00 & 40.00 & 56.67 & 43.33 \\
0.13 & 83.33 & 16.67 & 66.67 & 33.33 & 56.67 & 43.33 & 13.33 & 86.67 \\
0.25 & 10.00 & 90.00 & 10.00 & 90.00 & 7.67 & 92.33 & 0.00 & 100.00 \\
0.5 & 0.00 & 100.00 & 0.00 & 100.00 & 0.00 & 100.00 & 0.00 & 100.00 \\
\hline Control & 100.00 & 0.00 & 100.00 & 0.00 & 100.00 & 0.00 & 100.00 & 0.00 \\
\hline
\end{tabular}


Table 2. Sensitivity of Boophilus annulatus to peracetic acid.

\begin{tabular}{cccc}
\hline Time/minutes & LC 50 & LC 90 & Slope \\
\hline 2 & 0.172 & 0.250 & $7.95 \pm 1.43$ \\
5 & 0.144 & 0.267 & $4.76 \pm 0.71$ \\
20 & 0.103 & 0.256 & $3.23 \pm 0.44$ \\
\hline 30 & 0.061 & 0.141 & $3.57 \pm 0.54$ \\
\hline
\end{tabular}

Table 3. The effective lethal time of PAA against Boophilus annulatus.

\begin{tabular}{ccc}
\hline Conc. $\%$ & LT50 & LT90 \\
\hline 0.03 & 31.69 & 34.08 \\
0.06 & 31.60 & 141.83 \\
0.13 & 11.49 & 102.45 \\
\hline 0.25 & 0.02 & 3.02 \\
\hline
\end{tabular}

for a period of time sufficient to allow for the death of this one-host tick species [27].

Antiparasitic preparations and patented drugs as dust sprays and emulsions were tested against ticks and mites after that $10 \% \mathrm{BHC}[\mathrm{HCH}]+10 \%$ DDT were effective as dust. Ectoparasites were removed within 3 days; a second application was warranted 14 days after the first. Spray of $1.0 \%$ malathion and $0.5 \% \mathrm{HCH}$ also showed a good response leading to eradication within 2 days. Consequently, this treatment was effective for up to 33 days of ticks and 31 days for mites [45].

The susceptibility of B. microplus larvae after $24 \mathrm{~h}$ to various acaricides, amitraz, chlorpyrifos, fipronil, ivermectin, or permethrin was tested through larval immersion microassay, LIM. The EC50 values were $2.873,15.47,2.983,14.69$, and $2.764 \mu \mathrm{M}$, respectively [58].

Trials with the macrocyclic lactone products proved efficacy of such acaricides for control of $B$. microplus on pastured and stanchioned cattle by ap-

\begin{tabular}{|c|c|c|c|c|}
\hline $\begin{array}{l}\text { Conc. } \\
\%\end{array}$ & $\begin{array}{l}\text { Mean Preoviposition } \\
\text { period/days }( \pm \text { SE) }\end{array}$ & $\begin{array}{l}\text { Mean oviposition } \\
\text { period/days }( \pm \text { SE) }\end{array}$ & $\begin{array}{l}\text { Number of Laid } \\
\text { eggs (range) }\end{array}$ & $\begin{array}{c}\text { Mean number } \\
\text { of laid eggs ( } \pm \text { SE) }\end{array}$ \\
\hline 0.06 & $9.00 \pm 0.41^{c}$ & $11.50 \pm 0.65^{b}$ & $700-1000$ & $850.00 \pm 64.54^{b}$ \\
\hline 0.13 & $12.00 \pm 0.41^{b}$ & $9.00 \pm 0.41^{c}$ & $550-650$ & $597.50 \pm 20.56^{c}$ \\
\hline 0.25 & $14.75 \pm 0.48^{a}$ & $6.75 \pm 0.48^{d}$ & $400-500$ & $457.50 \pm 21.75^{c}$ \\
\hline Control & $8.50 \pm 0.65^{c}$ & $15.00 \pm 0.82^{\mathrm{a}}$ & $1500-2000$ & $1750 \pm 104.08^{a}$ \\
\hline
\end{tabular}

Table 5. Mortality percentage of Argas persicus after treatment with PAA.

\begin{tabular}{cccccccccccc}
\hline \multicolumn{2}{c}{60} & \multicolumn{2}{c}{30} & \multicolumn{2}{c}{20} & \multicolumn{2}{c}{ 2 } & Time/min \\
\hline Dead & Alive & Dead & Alive & Dead & Alive & Dead & Alive & Dead & Alive & Conc. \% \\
50.00 & 50.00 & 0.00 & 100.00 & 0.00 & 100.00 & 0.00 & 100.00 & 0.00 & 100.00 & 0.01 \\
100.00 & 0.00 & 30.00 & 70.00 & 10.00 & 90.00 & 0.00 & 100.00 & 0.00 & 100.00 & 0.03 \\
100.00 & 0.00 & 73.33 & 26.67 & 73.33 & 26.67 & 0.00 & 100.00 & 0.00 & 100.00 & 0.06 \\
100.00 & 0.00 & 83.33 & 16.67 & 83.33 & 16.67 & 83.33 & 16.67 & 0.00 & 100.00 & 0.13 \\
100.00 & 0.00 & 100.00 & 0.00 & 100.00 & 0.00 & 100.00 & 0.00 & 0.00 & 100.00 & 0.25 \\
100.00 & 0.00 & 100.00 & 0.00 & 100.00 & 0.00 & 100.00 & 0.00 & 100.00 & 0.00 & 0.50 \\
0.00 & 100.00 & 0.00 & 100.00 & 0.00 & 100.00 & 0.00 & 100.00 & 0.00 & 100.00 & Control \\
\hline
\end{tabular}




\begin{tabular}{cccc}
\multicolumn{4}{c}{ Table 6. Sensitivity of Argas persicus to peracetic acid. } \\
\hline Time/minutes & LC 50 & LC 90 & Slope \\
\hline 2 & 0.349 & 0.367 & $56.72 \pm 12$ \\
5 & 0.12 & 0.133 & $27.27 \pm 54$ \\
20 & 0.055 & 0.121 & $3.70 \pm 0.53$ \\
30 & 0.046 & 0.121 & $3.06 \pm 0.42$ \\
\hline 60 & 0.010 & 0.012 & $17.40 \pm 84$ \\
\hline
\end{tabular}

\begin{tabular}{|c|c|c|}
\hline Conc. \% & LT50 & LT90 \\
\hline 0.03 & 32.58 & 48.225 \\
\hline 0.06 & 17.187 & 34.896 \\
\hline 0.13 & 5.338 & 24.104 \\
\hline 0.25 & 3.122 & 3.348 \\
\hline
\end{tabular}

plying a pour-on or a subcutaneous injection. It worth to mention that pour-on treatment leads to control with eprinomectin (87.7\%), Ivermectin (84.7\%), and moxidectin $(78.7 \%)$ [15]. Similarly, the $88.6 \%$ therapeutic control resulted form a single treatment with the pour-on formulation of Doramectin [24].

Although the previously mentioned chemicals proved efficacy as acaricides against $B$. annulatus and B. microplus, our results may not be directly comparable to them because of using different localities and application techniques which mainly In vivo studies but PAA is an environmentally safe chemical $[10,60]$ combining lower concentrations and faster action against ticks.

Regardless of being effective against B. microplus, acaricide resistance was reported recently in peer reviewed journals to many classes of acaricides [23], including; chlorinated hydrocarbons (DDT) [23]; pyrethroids [24,50]; organophosphates [40]; carbaryl [4]; and formamidines, amitraz [5,17,24]. Resistance to carbaryl and cross-resistance patterns between carbaryl and organophosphorus acaricides suggests the involvement of a similar resistance mechanism [4]. Moreover, Klafke et al., [34] reported, for the first time, resistance of $R$. (B.) microplus to ivermectin using larval immersion tests (LIT). Therefore, using acaricides for control of ticks led to many problems, such as environmental pollution, development of resistant tick strains, and escalating costs [33].

Botanical pesticides represent an underused substitute to synthetic pesticides with a near unlimited potential of new discovery. An emulsion of tobacco leaf extract (100ml), 10\% DDT (100g); mustard oil (100 ml), copper sulphate $(20 \mathrm{~g})$, and water (320) were used for control ticks, including Boophilus. Eradication of ticks completed within 2 days. A second application was not required until 29 days after the first treatment [45].

Neem posses anti-tick activities, $\mathrm{CHCL}_{3}$ extracts of Melia azedarach showed higher effectiveness (14$100 \%$ ) against B. microplus engorged females than ethanolic extract (0-46\%) [11]. Moreover, neem is effective against the Egyptian tick, Hyalomma anatolicum excavatum (Kock, 1844) as Abdel-Shafy and Zayed [1] studied the effect of Azal F at concentrations of 1.6$12.8 \%$. It induced a significant increased in mortality rates of unfed adults reaching $100 \%$ on $15^{\text {th }}$ day posttreatment.

The effect of five essential oils belonging to the Family: Labiatidae: peppermint (Mentha piperita); spearmint (Mentha viridis); marjoram (Marjorana hortensis); lavender (Lavandula officinalis) and sweet basil (Ocimum basilicum) were tested in Egypt against fed females of the cattle tick B. annulatus. Dipping technique was used for 30 seconds, and the mortality was recorded after 3 days posttreatment. All experiential oils had effects on fed females, oil treatments (0.5-5\%) caused mortality rates of 6.7 to $98.3 \%, 5.6$ to $40 \%$; 56.7 to $90 \%$; 67 to $93.3 \%$; and 26.7 to $98 \%$ with the previous oils, respectively. The LC50 values were 2.85 , $10.57,0.52,3.25$, and $1.01 \%$, respectively [2]. 
Similar to our experiment, Abdel-Shafy and Soliman [2] used the same species, B. annulatus, and locality. Whereas they used different technique (dipping) for $30 \mathrm{sec}$. and they waited for 3 days till they got mortality readings, after that all essential oils possessed higher LC50 values than ours except for sweet basil oil. Accordingly, PAA gave better results than formerly stated oils because it required lower concentrations and killed ticks within few minutes.

Foam soap containing essential oil of Ageratum houstonianum leaves is toxic to Rhipicephalus anunulatus through subjecting to filter paper contact bioassay. The in vitro mortality rate was $95 \%$ with the lowest dose $(0.02 \mu \mathrm{l} / \mathrm{g})$ on day 8 and $100 \%$ with the highest dose $(0.03 \mu \mathrm{l} / \mathrm{g})$ on day 3 . The LD50 was 0.0259 $\mu \mathrm{l} / \mathrm{g}$ on day 2 after treatment [44].

Although Pamo et al. [44] used the same technique, they used not only different hard tick species and dose unites, but also they recorded the mortality readings after much longer time, 8 days than ours. Hence our records may not be directly analogous with them.

Laboratory bioassays were conducted to determine the activity of 15 natural products isolated from essential oil components extracted from the heartwood of Alaska yellow cedar, Chamaecyparis nootkatensis, against Ixodes scapularis Say nymphs. Carvacrol is the monoterpene that demonstrated biocidal activity against ticks with LC50 values after $24 \mathrm{~h}$ of $0.0068 \%$ (wt: vol). Nootkatone was the most effective of the eremophilane sesquiterpenes against ticks $($ LC50 $=0.0029 \%)$, LC50 of the crude essential oil was $0.151 \%$ [46].

Even though, Carvacrol and nootkatone gave lower LD50 values than ours, such estimates were calculated after longer time of exposure time, 24h. Moreover, they are less stable than the crude oil [46] on the other hands; we got similar LC50 values to that of the essential oil but after shorter time, 5 min.

The acaricidal effect of essential oil of Melaleuca alternifolia (tea tree oil, TTO) was tested against nymphs of Ixodes ricinus at different doses (4-10 $\mu$ l) and for different exposure times (30-120 min.). A dose of $8 \mu \mathrm{TTO}$ was lethal for more than $59 \%$ of ticks when inhaled a significant effect being observed after $90 \mathrm{~min}$. of exposure [32].

Comparable to our data, the acaricidal effect was in a direct correlation with the exposure time, but the killing effect was observed after longer time, $90 \mathrm{~min}$.
Regarding the microbial control of hard ticks, the potential activity of three varieties of Bacillus thuringiensis against the hard tick Hyalomma dromedarii was investigated in Egypt by Hassanain et al. [29], where ticks died between $48 \mathrm{~h}$ and 10 days posttreatment. Dipel $2 \mathrm{x}$ (B. thuringiensis var. kurstaki) was the most potent, followed by Vectobac (B. thuringiensis var. israeliensis), then HD 703 (B. thuringiensis var. thuringiensis).

Because different bioassay techniques were used in the previous acaricidal, botanical, and microbial studies, our results may not be directly comparable with theirs. In our study, we used the filter paper contact bioassay that we suggest is more expressive of what would occur in nature. We expect PAA to be applied to artificial and naturally occurring substrates both indoors and outdoors to control ticks. In either case, ticks would directly contact compounds, as they do in the filter paper imitating circumstances presented in the field.

In comparison, PAA demonstrated greater effectiveness than all previously mentioned materials because it is sufficiently toxic to be effective in both lower doses and extremely short time. It represents a potentially safe and successful alternative to chemically engineered compounds currently being used by pest control operators and individual homeowners. Also the high speed of killing ticks is an added value of such safe chemical to avoid the risk of pathogen transmission through delayed mortality [54].

For the reason that the contact kill rate of a contestant acaricide could be an important factor to judge before conducting In vivo studies, we were concerned in establishing speed kill rate level for PAA in a filter paper contact bioassay as the main objective is to search for a broad spectrum acaricide which act within extremely short time and are approved for medical and veterinary use. To date, no acaricide used to fulfils this demand.

After treatment with PAA against hard tick, at 0.03-0.25\%, the LT50 values were 31.69-0.02 min.

It is substantial to point out to the striking similarities in susceptibility profiles between Amblyonna americanum and B. microplus [58]. Therefore, we compare our time response data with that revealed by the same author who exposed A. americanum larvae to a single level of some acaricides that was calculated to yield 99\% tick mortality under LIM. Mortality approaching or exceeding $99 \%$ was seen with all acaricides 
at $24 \mathrm{~h}$ interval. Nevertheless, ET50 values of 6.06, $4.63,11.7$, and $4.44 \mathrm{~h}$ for amitraz, chlorpyrifos, fipronil, and ivermectin, respectively. The ET50 value for permethrin was < $30 \mathrm{~min}$ [58].

The information in peer reviewed journals recounting that significantly toxic effect being observed after using acaricides after days or even weeks, slowdeath syndrome; $24 \mathrm{~h}$ [58], 3 days [45] and 23 days posttreatment [24]. On the other hands, the minimal significant effectiveness of plant extracts appeared after 90 min [32]; 24 h [46]; 2 days [45]; 3 days [2,44]; and finally, 15 days [1].

The importance of delayed death of the treated ticks considered as strong circumstantial evidence of the risk that ticks can present to humans and animals at the initial stages of poisoning after acaricide treatment [54].

Along with its effectiveness against adult stage, PAA caused detrimental effect to the survived engorged females concerning their reproductive potential; it not only prolonged of the oviposition periods, but shortened the oviposition periods and decreased the number of laid eggs as well.

Similar adverse effect on the biological parameters of ticks was recorded after treatment with acaricides. Due to the fact that $B$. microplus is similar in biology to $B$. annulatus [48], we compare our result mainly to those recorded for B. microplus. Sublethal concentrations adversely affect the reproductive capability, carbaryl inhibited female oviposition and egg hatching [39] besides $M$. azedarach extracts reduced partially or totally egg production and embryogenesis [11]. Furthermore, doramectin, a pour-on application or subcutaneous injection, adversely affect the mean weights and egg masses [24].

Analogous adverse effect on the biology was also noticed for $H$. dromedarii [19,29]. The relationship between the efficacy of $1 \%$ flumethrin in pour-on formulation on the fertility of engorged female by using a contact method, ticks were exposed in vitro to $87 \mu \mathrm{g}$ active ingredient. Exposure for 5 or $10 \mathrm{~min}$. reduced the percentage of females ovipositing, egg mass weight, number of eggs, percentage of females laying eggs that hatch and the conversion efficiency of female weight to egg mass weight. The pre-oviposition and egg incubation periods of females exposed for 1,5 or $10 \mathrm{~min}$ were prolonged due to the action of the drug [19].
Eggs of $H$. dromedarii were mostly affected at 25 days following treatment with three varieties of Bacillus thuringiensis [29].

With appearance of modern and confined techniques of rearing poultry, infestations of the fowl tick are rare and usually limited to small flocks of chickens maintained for personal use [16]. Recently, there is limited information about the effects of A. persicus on poultry production in terms of weight gain, egg production, and other parameters as well as control measures of such pest.

PAA was very effective against $A$. persicus when applied at $0.13-0.5 \%$ for $2-60 \mathrm{~min}$. accordingly; the LC50 values were $0.35-0.01 \%$ and LT50 values were 32.58-3.12. min, after treatment with $0.03-0.25 \%$.

Similar to hard ticks, $100 \%$ mortality was reached after 2 min. posttreatment with the highest concentration, $0.5 \%$, as well as similar LC50 values after $30 \mathrm{~min}$. On the other hands, soft ticks are more sensitive to PAA than hard ticks because almost all ticks were died after treatment with the used concentration after $60 \mathrm{~min}$. Therefore, we did not make follow up to the survived soft ticks as previously mentioned for hard ticks.

N.B: The in vivo study was done only for $A$. persicus control by means of a through spray of all parts of hen house and floor litter plus fowl treatment with $0.5 \%$ PAA. Excellent results against soft tick infestation in the small flocks of chicken uphold for private use near Benha city, Data not shown.

Control of the fowl tick was mainly done by using of synthetic-chemical acaricides. In the past, several workers applied through spraying of poultry houses with kerosene, kerosene emulsion, benzene, gasoline, dusting with carbolated lime, panting with lime whitewash or fumigation with sulfur [43]; a thorough spraying of poultry structures with nicotine sulfate [9]; and premises treatment with carbolineums, crude petroleum, creosote oil, proper houses, roost, and nest construction [8].

During the fifties, several authors reported some new insecticides, at that time, sprays of lindane, chlordane, toxaphene, dieldrin, and aldrin provided some control of the fowl tick [53]; sprays of malathion and diazinon when applied to wooden feeding troughs on large range-type commercial turkey feedlots [49]. Finally, a premise spray plus fowl treatment of carbaryl controlled A. persicus, sprays of naled and ronnel gave 
less conclusive results; whereas, trichlorfon was ineffective [35].

Permethrin, propoxur, and diazinon were tested against $A$. persicus in a test of susceptibility and in a multiple choice test in bioassay. The lethal values were calculated at $7^{\text {th }}$ day of treatment. Permethrin was the most toxic (LC95 was $0.5-1.4 \mathrm{mg} \mathrm{m}^{-2}$, depending on the developmental stage) and the most repellent acaricide. The mortality of males in the bioassay was significantly higher (76.7-94.3\%) when acaricide in amounts of 16 and $160 \mathrm{mg}$ of active ingredient per filter paper disc were mixed with attractant $(0.5 \mathrm{mg}$ per filter paper disc) instead of acaricide alone (20-45.7\% mortality only). Propoxur was less toxic (LC95 was $0.9-1.9 \mathrm{mg}^{-2}$ ) and diazinon the least toxic (LC95 was 2-9.4 $\mathrm{mg} \mathrm{m}^{-2}$ ), both being not or only slightly repellent [18].

In contrast to the available information for hard tick control, there is no available information regarding the control of fowl tick with botanically based products.

Concerning the use of microbial control of $A$. persicus, the prospective efficiency of three varieties of $B$. thuringiensis was examined in Egypt. Soft ticks succumbed within a period ranging from $36 \mathrm{~h}$ to 5 days. Dipel $2 \mathrm{x}$ (B. thuringiensis var. kurstaki) was the most potent, followed by Vectobac (B. thuringiensis var. israeliensis), then HD 703 (B. thuringiensis var. thuringiensis). Eggs were mostly affected at 16 and 25 days after deposition [29].

Our data may not be unswervingly comparable to the previous studies controlling fowl ticks because of using different bioassay techniques and localities. PAA was highly effective against $A$. persicus within extremely short time, because $100 \%$ mortality occurred after $2 \mathrm{~min}$. Consequently, PAA possed faster acaricidal effect than that reported by Dusbábek. et al. [18], 7 days and Hassanain et al. [29], $36 \mathrm{~h}$ to 5 days.

In general, all the previously mentioned studies reported delay morality of ticks for days or even weeks in case of hard and soft ticks. On the other hands, the rapid-death syndrome caused by PAA is very important to avoid the risk of transmission of pathogen by ticks having gradual and progressive development of toxic symptoms.

To clarify this crisis, Uspensky and Uspensky [54] obtained data during more than three decades of work with ticks of various species and with acaricides of different groups. The first important phenomenon found was the gradual and progressive development of toxic symptoms after acaricide application. When ticks are at the initial stages of poisoning, they can attach to hosts and imbibe blood. Engorged nymphal ticks normally molted to adults, engorged females normally oviposited, and their progeny did not differ from the progeny of control females. The second important phenomenon, called "overcoming the poisoning" which allows the ticks to survive and makes possible the subsequent transstadial and transovarial passage of pathogens.

On the subject of the insecticidal and acaricidal properties of PAA, there are very few literatures dealing with such topic. Comparable to our results, PAA controlled fish ectoparasites, Ichthyobodo necator "Costia" naturally infecting brown trout, Salmo trutta [31]; furthermore, PAA and hydrogen peroxide produce good control of thrips when properly used and in the case of conserve at the highest application rate [26].

In contrast, You et al. [61] found that PAA (2.5\%) did not kill soil mites (Oribatidae) that are the intermediate hosts of Anoplocephalidae. In order to explain this phenomenon, we suggest that soil mite did not response to PAA because of the fact revealed by Anderson and Miller [3] as low doses of PAA induce promoter activity of the gene encoding catalase A and increased total catalase specific activity in cell extract of Pseudomonas putida. Consequently, microbes present in agricultural soils rapidly degraded the active oxygen species (AOS) present in PAA because of catalase activity. Therefore, the same authors suggests that catalase activity of microbial cells in suspension or in association with surfaces would lead to breakdown of AOS in PAA if dose did not immediately cause bacterial cell death.

Due to high resistance of bacterial spores to chemical and physical agents, the sporocidal activity is commonly used to evaluate disinfecting and sterilizing agents [6]. Consequently, PAA has an excellent and reliable activity against spores and chemical resistant microorganisms, such as; the most resistant poliovirus type 1 and the adenovirus type 2, in addition to spores of different Clostridial species [59]; the chemical resistant Salmonella typhimurium 28b phage and Ascaris suum eggs [55,56]; drug resistant isolates of $M$. tuberculosis and M. avium complex [30]; and free swimming Fusarium oxysporum clamydospores [28].

In our experiments, PAA has very rapid lethal effect against ticks. As a result, LT50 value for B. annu- 
latus and A. persicus were 0.02 and $3.12 \mathrm{~min}$, respectively, after exposure to $0.25 \%$.

Similarly, several workers reported faster germicidal outcome of PAA when applied to a wide range of microorganisms. After $30 \mathrm{sec}, 100 \mathrm{ppm}$ of PAA sanitize fresh cut mango which had less contamination, $<1$ Colony Forming Unit, CFU [42].

As soon as 5 min. of exposure, PAA was a rapid mycobacericidal agent even against drug resistant isolates of $M$. tuberculosis and M. avium complex [30].

Regarding control of Cryptosporidium, after treatment of oocysts for $5 \mathrm{~min}$., an excystation index of Zero compared to 0.02 for glutraldehyde after 60 min of exposure [30]. In contrast to another experiment done by Quilez et al., [47], whereas 10\% OXVirin, containing hydrogen peroxide plus peracetic acid, was used for longer time, $60 \mathrm{~min}$, and the excystation assay showed $98.6 \%$ inactivation, while the vitaldye assay showed $95.2 \%$ inactivation and the infectivity assay revealed $100 \%$ inactivation of oocyts.

Within 15 min, $0.2 \%$ PAA inactivated the most resistant poliovirus type 1 and the adenovirus type 2 [60]. Subsequent to $1 \mathrm{~h}$ post application, PAA (as 1\% Jet 5) was effective in killing free swimming $F$. oxysporum clamydospores, causing basal rot, whereas total kill was not achieved with formaldehyde $0.5 \%$ commercial formalin (38-40\%) after 4h [28].

Quite the opposite, relatively longer time was consumed when PAA was applied for controlling microorganisms in toilet waste and during processes of poultry production. Following treatment for $12 \mathrm{~h}$, Vinneras [55] recorded efficient and reliable disinfection method for toilet waste using peracetic acid (0.5$1 \%$ ) as it reduced all of the following indicator organisms, Escherichia coli, Enterococcus spp., and Salmonella spp, together with the chemical resistant Salmonella typhimurium $28 \mathrm{~b}$ phage and Ascaris suum eggs. With regard to poultry production, PAA extended the shelf life time of chicken drumettes by 3 days by reducing the number of the inoculated zoonotic bacteria [25] and produce $85.5 \%$ reduction of the total fungal count after $24 \mathrm{~h}$ application to broiler-breeder hatching eggs in Egypt [41].

The mode of action of PAA as acaricide is not known, as this is the first report of such oxidizing agent against ticks. On the other hands, the mechanism of virucidal action of PAA was revealed by several researchers, thus we expected somehow similar mode of action against ticks, by its nonspecific oxi- dizing effect, PAA likely acts on SH-, OH-, and NHgroups of amino acid, nucleotides, and unsaturated fatty acids. Thus it is able to interact with lipid and protein components of viral envelope, to denature viral capsid proteins and to inactivate nucleic acids of the viral genome [36,37]. As shown by electron microscopic observation, PAA can completely destroy the structure of virus particles [38]. On the other hands, the oxidative stress impaired heme detoxification in the midgut of B. microplus, consequently; it diminished life span, oviposition, and engorgement [13].

As many other disinfectants, PAA is somewhat irritant but fortunately it is very effective in very low concentrations.

Regarding safety of PAA and its application, several authors discussed such topic revealing strong germicidal, including virucidal properties of PAA which have been accepted for many years $[10,60]$.

When used as pre-planting treatment, PAA was at least as good as formaldehyde, with no phytotoxicity and no detrimental effect on healthy Narcissus bulbs and stocks after that giving the highest bulb yield especially when PAA controlled nematode in combination with thiabendazol. [28].

Regarding water treatment, PAA is a good biocidal candidate for inactivation of pathogenic Naegleria lovaniensis in cooling water systems and used as an alternative to hypochlorite which induce negative impact on aquatic environment, whereas; PAA is ecologically less harmful [20]. Moreover, after disinfectant in Lake water, non of the water concentrates showed any cytotoxic effect or variations in glutathione content $(\mathrm{GSH})$, free radical production (ROS), and cytochrome P4501A3 [21].

Concerning disinfection of toilet water, PAA represents an effective and reliable treatment of fecal matter and safe recycling of nutrients [55]. Furthermore, its application to effluents before their emission in water bodies, PAA does not lead to formation of significant amounts of genotoxic by-products [14].

\section{CONCLUSION}

Control of ticks presents many great research challenges and prospect in the identification of new acaricides that the public perceives as safe and environmentally acceptable. The study therefore established that PAA was toxic to ticks and the toxicity was directly proportional to the concentration of the chemical. The high acaricidal activity at low concentrations, short exposure time, and non toxic by-products 
seemed to make PAA as a suitable new acaricide for medical and veterinary use as well as an alternative to the used synthetic acaricides.

\section{FURTHER STUDIES}

PAA merit further study as a potential acaricide agent. Future research will include efficacy of this product as a repellent, topical treatments for mammals, mode of action, and enhancement of activity by adding synergists and stablizers.

Acknowledgment. The authors thank N.E. Ahmed (Faculty of Veterinary Medicine, Benha University) and O.M.E. ElAzazi (Faculty of Veterinary Medicine, Zagazig University) for their help and support.

\section{REFERENCES}

1 Abdel Shafy S. \& Zayed A.A. 2002. In vitro acaricidal effect of plant extract of neem seed oil (Azadirachta indica) on egg, immature, andadult stages of Hyalomma anatolicum excavatum (Ixodoidea, Ixodidae). Veterinary Parasitology. 16: 89-96.

2 Abel-Shafy S. \& Soliman M.M. 2004. Toxicity of some essential oils on eggs, larvae and females of Boophilus annulatus (Acari, Ixodidae, Amblyommidae) infesting cattle in Egypt. Acarologia. XLIV: 23-30.

3 Anderson A.J. \& Miller C.D. 2001. Catalase activity and the survival of pseudomonas putida a root colonizer, upon treatment with peracetic acid. Canadian Journal of Microbiology. 47: 222-228.

4 Andrew Y.L., Davey R.B. \& George J.E. 2005. Carbaryl resistance in Mexican strains of the southern cattle tick (Acari, Ixodidae). Journal of Medical Entomology. 98: 552-556.

5 Andrew Y.L., Davey R.B., Miller R.J \& George J.E. 2004. Detection of characterization of amitraz resistance in the southern cattle tick, Boophilus microplus (Acari, ixodidae). Journal of Medical Entomology. 41: 193-200.

6 Beloian A. 1990. Disinfectants. In AOAC Official methods of analysis (Ed). Helrich, K. PP. 133-146. Arlington, TX, Association of official analytical chemists.

7 Bishopp F.C. 1919. The fowl tick and how premises may be freed from it. U.S. Dep. Agric. Farmer's Bull., 1070.

8 Bishopp F.C. 1942. Poultry mites, U. S. Dep. Agric. Yearb. Agric., 1055.

9 Bishopp F.C. \& Wagner R.D. 1931. Nicotine in the control of ectoparasites of poultry. Journal of Economic Entomology. $24,56$.

10 Block S.S. 1991. Peroxygen compounds. In Disinfection, sterilisation, and preservation ed. Block, S. S. PP. 167-181. Philadelphia, PA, Lea \& Febiger.

11 Borges L.M.F., Ferri P.H., Silva W.J., Silva W.C. \& Silva J.G. 2003. In vitro efficacy of extracts of Melia azedarach against the tick Boophilus microplus.

12 Chaton P F., Ravanel P., Tissut M. \& Meyran J.C. 2002. Toxicity and bio accumulation of fipronil in the nontarget arthropodan fauna associated with subalpine mosquito breeding sites. Ecotoxicological Environmental Safety. 52: 8-12.

13 Citelli M., Lara F.A., Vaz Jr. I.S. \& Oliveira P.L. 2006. Oxidative stress impairs heme detoxification in the midgut of thle cattle tick, Rhipicephalus (Boophilus) microplus. Molecular and Biochemical Parasitology. 1317123644.

14 Crebelli R., Conti L, Monarca S., Feretti D., Zerbini I., Zani C., Veschetti E., Cutilli D \& Ottaviani M. 2005. Genotoxicity of the disinfection by-products resulting from peracetic acid or hypochlorite-disinfected sewage wastewater. Water Research. Oxford. 39: 1105-1113.

15 Davey R.B. \& George J.E. 2002. Efficacy of Macrocyclic Lactone Endectocides against Boophilus microplus (Acari, Ixodidae) Infested Cattle Using Different Pour-On Application Treatment Regimes. Journal of Medical Entomology. 39: 763-769

16 Drummond R.O., George J.E. \& Kunz S.E.(Ed). 1988. Control of arthropod pests of livestock, A review of technology. CRC Press Inc. pp 1-19 \& 145-158.

17 Ducornez S., Barre N., Miller R.J. \& Garine-Wichatitsky M.D. 2005. Diagnosis of amitraz resistance in Boophilus microplus in New Caledonia with the modified larval packet test. Veterinary Parasitology. 130, 285-292.

18 Dusbábek F., Rupes V., Sbreveimek P., Zahradni'ckova' H. 1997. Enhancement of permethrin efficacy in acaricide-attractant mixtures for control of the fowl tick Argas persicus (Acari: Argasidae). Experimental and Applied Acarolology. 21: 293-305.

19 El-Azazy O.M.E. \& Lucas S.F. 1996. The sterilizing effect of pour-on flumethrin on the camel thick, Hyalomma dromedarii (Acari: Ixodidae). Veterinary Parasitology. 61: 339-343.

20 Ercken D., Verelst L., Declerck P., Duvivier L., Damme.A.V. \& Ollevier F. 2003. Effects of peracetic acid and monochloramine on the inactivation of Naegleria lovaniensis. Water Science and Technology. 47: 167-171. 
21 Ferraris M., Chiesara E., Radice S., Giovara A., Frigerio S., Fumagalli R. \& Marabini L. 2005. Study of potential toxic effects on rainbow trout hepatocytes of surface water treated with chlorine or alternative disinfectants. Chemosphere. 60 : $65-73$.

22 Finney D.J. 1971. Probit analysis, a statistical treatment of sigmoid response curve. Cambridge University Press.

23 Foil L.D., Coleman P., Eisler M., Fragoso-Sanchez H., Garcia-Vazques Z., Guerrero F.D., Jonsson N.N. Langstaff I.G., Li A.Y. \& Machila, N. 2004. Factors that influence the prevalence of acaricide resistance and tick-borne diseases. Veterinary Parasitology 125: 163-181.

24 George J.E \& Davey R.B. 2004. Therapeutic and Persistent Efficacy of a Single Application of Doramectin Applied Either as a Pour-on or Injection to Cattle Infested with Boophilus microplus (Acari, Ixodidae). Journal of Medical Entomology. 41: 402-407.

25 Ghadeer M., Blank G., Han J.H., Hydamaka A. \& Holley R.A. 2005. Effectiveness of trisodium phosphate, lactic acid and commercial antimicrobials against pathogenic bacteria on chicken skin. Food Protection Trends. 25: 351-362.

26 Gill S.A., Reeser R. \& Raupp M.J. 1998. Battling thrips, five pesticides put to the test. Grower Talks. 62, 46-48.

27 Graybill H.W. 1912. Methods of exterminating the Texas fever tick, U.S. Dep. Agric. Farmer's Bulletin. 498.

28 Hanks G.R. \& Linfield C.A. 1999. Evaluation of a peroxyacetic acid disinfectant in hot-water treatment for the control of basal rot (Fusarium oxysporumf. sp. Narcissi) and stem nematode (Ditylenchus dipsaaci) in narcissus. Journal of Phytopathology. 147: 217-279.

29 Hassanain M.A., El Garhy M.F., Abdel-Ghaffar F.A., El-Sharaby A. \& Abdel-Megeed K.N. 1997. Biological control studies of soft and hard ticks in Egypt. I. The effect of Bacillus thuringiensis varieties on soft and hard ticks (Ixodidae). Parasitology Research. 83: 209-213.

30 Holten J., Shetty N. \& MecDonald M. 1995. Efficacy of "Nu-Cidex" (0.35\% peracetic acid) against mycobacterial and cryptosporidia. Journal of Hospital Infection. 31: 235-237.

31 Holten K., Skjelstad B., Aunsmo A. \& Skjelstad H.R. 2003. Effect of DetaroxReg. AP against infection with Ichthyobodo necator. Norsk Veteriaertidsskrift. 115: 719-723.

32 Iori A., Grazioli D., Gentile E., Marano G. \& Salvatore G. 2005. Acaricidal properties of the essential oil of Melaleuca alternifolia Cheel (tea tree oil) against nymphs of Ixodes ricinus. Veterinary Parasitology. 129: 173-176.

33 Kayaa G.P. 1992. Non-chemical agents and factors capable of regulating tick populations in nature, A min-review. Insect Science and its Application. 13: 587-594.

34 Klafke G.M., Sabatini G.A., Albuquerque T.A., Ricardo Martins, J., Kemp D.H, Miller R.J. \& Schumaker. T.S. 2006. Larval immersion tests with ivermectin in populations of the cattle tick Rhipicephalus (Boophilus) microplus (Acari: Ixodidae) from State of Sao Paulo, Brazil. Veterinary Parasitology. 142: 386-390

35 Kraemer P. 1959. Relatively efficacy of several materials for control of poultry ectoparasites. Journal of Economic Entomology 52, 1195.

36 Maillard J.Y., Beggs T.S., Day M.K., Hudson R.A., \& Russell A.D. (1996a). Damage of Pseudomonas aeruginosa PAOI bacteriophage F116 by biocides. Journal of Applied Bacteriology. 80: 540-544.

37 Maillard J.Y., Beggs T.S., Day M.K., Hudson R.A., Russell A.D. 1996b. The effect of biocides on proteins of Pseudomonas aeruginosa PAO bacteriophage F116. Journal of Applied Bacteriology. 80: 291-295.

38 Maillard J.Y., Hann A.C., Beggs T.S., Day M.K., Hudson R.A. \& Russell A.D. 1995. Electron-microscopic investigation of the effect of biocides on Pseudomonas aeruginosa PAO bacteriophage F116. Journal of Medical Microbiology. 42: 415-420.

39 Mansingh A. \& Rawlins S.C. 1979. Inhibition of oviposition in the cattle tick, Boophilus microplus by certain acaricides. Pesticide Science. 10: 485-494.

40 Miller R.J., Davey R.B. \& George J.E. 2005. First report of organophosphate-resistant Boophilus microplus (Acari, Ixodidae) within the United states. Medical Entomology. 42: 912-917.

41 Moustafa G.Z. 2004. Effect of sanitation on the microbial load and hatchability of broiler breeder eggs. Veterinary Medical Journal of Giza. 52: 575-587

42 Narciso J. \& Plotto A. 2005. A comparison of sanitation systems for fresh-cut mango. HortTechnology. 15: 837-842.

43 Osborn H. 1896. Insects affecting domestic animals, an account of the species of importance in North America with mention of related forms occurring on other animals. U. S. Department Agricultural Bulletin. 5.

44 Pamo E.T., Tendonkeng F., Kana J.R., Payne V.K., Boukila B., Lemoufouet J., Miegoue E. \& Nanda A.S. 2005. A study of the acaricidal properties of an essential oil extracted from the leaves of Ageratum houstonianum. Veterinary Parasitology. 128: $319-323$. 
45 Pandita N.N. \& Ram S. 1990. Control of ectoparasitic infestation in country goats. Small ruminant research. 3: 403-412. 46 Panella N.A., Dolan M.C., Karchesy J.J, Xiong Y., Peralta-Cruz J., Khasawneh M., Montenieri J.A. \& Maupin G.O. 2005. Use of Novel Compounds for Pest Control, Insecticidal and Acaricidal Activity of Essential Oil Components from Heartwood of Alaska Yellow Cedar. Journal of Medical Entomology. 42: 352-358.

47 Quilez J., Sanchez-Acedo C., Avendano C., Cacho E.D. \& Lopez-Bernad F. 2005. Efficacy of two peroxygen-based disinfectants for inactivation of Cryptosporidium parvum oocysts. Applied and Environmental Microbiology. 71: $2479-2483$.

48 Roberts L.S. \& Janovy J. 2005 ( $7^{\text {th }}$ Ed). Foundations of parasitology. McGraw Hill. 644-646 pp.

49 Rodriguez J.L. \& Riehl Jr. L.A. 1956. Four pesticides tested against the fowl tick infesting turkeys in feed lots, Journal of Economic Entomology. 49: 713.

50 Rosario-Cruz R., Guerrero F.D., Miller R.J., Rodriguez-Vivas R.I., Dominguez-Garcia D.I., Cornel A.J., MernandezOrtiz R. \& Goerge J. E. 2005. Roles played by estrase activity and by a sodium channel mutation involved in pyrethroids resistance in populations of Boophilus microplus (Acari: Ixodidae) collected from Yucatan, Mexico. Journal of Medical Entomology. 42: 1020-1026.

51 Schulze T.L., Jordan R.A., Hung R.W., Krivenoko Jr., Schulze J.J. \& Jordan T.M. 2001. Effects on application of granular carbaryl on nontarget forest floor arthropods. Journal of Economic Entomology. 94: 123-128.

52 Shah A.H., Khan M.N., Iqbal Z., Safid M.S. \& Akhtar M.S. 2006. Some epidemiological aspects and vector role of tick infestation on layers in the Faisalabad district (Pakistan). World's Poultry Science Journal. 62: 145-157.

53 Smith C.L. 1952. Field tests of insecticides against ectoparasites of poultry. Journal of Economic Entomology. 45 : 748.

54 Uspensky I. \& Uspensky I.I. 2006. Potential risk of pathogen transmission by acaricide-poisoned ticks. International Journal of Medical Microbiology. 296: 217-224.

55 Vinneras B. 2002. Possibilities for sustainable nutrient recycling by faecal separation combined with urine diversion. Acta Univesitatis Agricultrae Sueciae- Agraria. 355: 88-93.

56 Vinneras B., Holmqvist A., Bagge E., Albihn A. \& Jonsson H. 2003. The potential for disinfection of separated fecal matter by urea and by peracetic acid for hygienic nutrient recycling. Bioresource Technology. 89: 155-161.

57 Wall R. \& Shearer D. (Ed.) 1997. Veterinary Entomology. Chapman and Hall. 97-140 \& 132-133 pp.

58 White W.H., Bauer S.M., Zhao X., Gutierrez J.A. \& Smith C.K. 2004. Comparison of In Vitro and In Vivo Ectoparasiticide Activity of Experimental Benzimidazole-Carbamate with Permethrin and Amitraz. Journal of Medical Entomology. 42: 207-211.

59 Wutzler P. \& Sauerbrei A. 2000. Virucidal activity of a combination of $0.2 \%$ peracetic acid and 80\% (v/v) ethanol (PAAethanol) as a potential hand disinfectant. Journal of Hospital Infection. 46: 304-308.

60 Wutzler P. \& Sauerbrei A. 2004. Virucidal activity of the new disinfectant monopercitic acid. Letters in Applied Microbiology. 39: 194-198.

61 You Y. G., YounHua C., GuoRun S., WanHai C. \& JianGuo C. 2002. Trails of the lethal efficacy of phenol and other pesticides against soil mites. Chinese Journal of Veterinary Medicine. 28:14-15. 